\title{
Miniplate fixation for the repair of segmental mandibular defects filled with autogenous bone in cats ${ }^{1}$
}

\author{
Uso de miniplacas na fixação de mandíbulas de gatos com defeitos \\ segmentares preenchidos com osso autógeno
}

\begin{abstract}
Adelina Maria da Silva', Wilson Machado de Souza", Marion Burkhardt de KoivistoIII, Patrícia de Athayde BarnabéIV, Nair Trevizan Machado de Souzav

${ }^{1}$ Research performed at Department of Clinics, Surgery and Animal Reproduction, Division of Veterinary Surgical Technique, Sao Paulo State University (UNESP), Araçatuba-SP, Brazil.

${ }^{\mathrm{I}} \mathrm{PhD}$, Assistant Professor, Department of Clinics, Surgery and Animal Reproduction, UNESP, Araçatuba-SP, Brazil. Responsible for conception, design, intellectual and scientific content of the study. Acquisition and interpretation of data: surgical procedures and radiographic examinations. Manuscript writing. Statistical analysis.

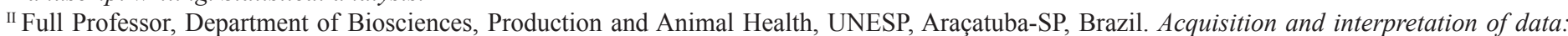
macroscopic and histopathological examinations. Critical revision.

III Associate Professor, Department of Clinics, Surgery and Animal Reproduction, UNESP, Araçatuba-SP, Brazil. Acquisition and interpretation of data: histometric examinations.

IV PhD, DVM, Department of Clinics, Surgery and Animal Reproduction, UNESP, Araçatuba-SP, Brazil. Acquisition and interpretation of data: histometric examinations.

${ }^{\mathrm{V}} \mathrm{PhD}$, Zootechnist, Department of Biosciences, Production and Animal Health, UNESP, Araçatuba-SP, Brazil. Acquisition and interpretation of data: macroscopic and histopathological examinations.
\end{abstract}

\begin{abstract}
Purpose: To evaluate the use of maxillofacial miniplate 1.5 in the repair of segmental mandibular defects filled with autogenous bone in cats. Methods: Twelve adult cats were divided into two groups. A segmental defect of $4 \mathrm{~mm}$ was created in one of the hemimandibles and filled with autogenous iliac crest bone graft. The operated hemimandible was fixed with a $1.5 \mathrm{~mm}$ titanium miniplate. In group 1 ( $\mathrm{n}=6$ ), the defect was performed in the body of the mandible, behind the $1^{\text {st }}$ molar. In group $2(n=6)$, the defect was performed between the $4^{\text {nd }}$ premolar and $1^{\text {st }}$ molar, with extraction of the $1^{\text {st }}$ molar. Oral alimentation was reinitiated 24 hours after surgery. Cats were euthanized at 20 weeks postoperative. Results: Incorporation of the graft was suggested by the radiographs taken 20 weeks after surgery. Macroscopic examination confirmed alignment and bone union of operated hemimandibles. Histological examination showed formation of woven bone in rostral and caudal mandible/graft interfaces. The percentage of bone tissue at these areas was measured by the histometry. There was no statistically significant difference between the values of group 1(64.48 \pm 4.51) and group 2 (71.69 \pm 14.47 ) (Mann-Whitney's test $\mathrm{p}=0.294)$. Conclusion: The use of miniplate 1.5 for the fixation of mandibular defects filled with autogenous bone in cats provided the main goals in the treatment of mandibular fractures: bone union, normal dental occlusion and immediate return to oral alimentation.
\end{abstract} Key words: Surgery, Oral. Fracture Fixation, Internal. Bone Transplantation. Mandible. Cats.

\section{RESUMO}

Objetivo: Avaliar o uso de miniplacas na fixação de mandíbulas de gatos com defeitos segmentares preenchidos com osso autógeno. Métodos: Foram utilizados 12 gatos adultos divididos em dois grupos de seis animais cada. Em uma das hemimandíbulas foi criado um defeito segmentar de $4 \mathrm{~mm}$, preenchido com enxerto autógeno do osso ilíaco. A hemimandíbula operada foi fixada com uma miniplaca 1.5 de titânio. No grupo 1 , o defeito foi realizado caudalmente ao $1^{\circ}$ molar e no grupo 2 , entre o $4^{\circ}$ pré-molar e $1^{\circ}$ molar, com extração do $1^{\circ}$ molar. A alimentação oral foi reiniciada 24 horas após a cirurgia. Os animais foram submetidos à eutanásia 20 semanas após a cirurgia. Resultados: As radiografias realizadas 20 semanas após a cirurgia sugeriram a incorporação do enxerto. O exame macroscópico confirmou redução cirúrgica satisfatória e união óssea das hemimandibulas operadas. Os exames histológicos demonstraram a presença 
de tecido ósseo esponjoso nos locais de transição do enxerto com o osso da mandíbula. Os exames histométricos demonstraram que não houve diferença estatisticamente significante nos valores observados de porcentagem de tecido ósseo nas áreas de incorporação do enxerto das hemimandíbulas operadas dos gatos do grupo $1(64,48 \pm 4,51)$ e grupo $2(71,69 \pm 14,47)$ (Teste de Mann-Whitney $\mathrm{p}=0$,294). Conclusão: Os resultados deste experimento permitiram concluir que o uso de miniplacas na fixação de mandíbulas de gatos com defeitos segmentares preenchidos com osso autógeno garante os principais objetivos no tratamento de fraturas da mandíbula: união óssea, oclusão dentária normal e alimentação oral imediata.

Descritores: Cirurgia Bucal. Fixação Interna de Fraturas. Transplante Ósseo. Mandíbula. Gatos.

\section{Introduction}

The treatment of mandibular and maxillofacial fractures in humans was revolutionized with the advent of miniplates. Miniaturized implants minimize tissue trauma and preserve periosteal blood supply. Besides that, smaller plate systems are desirable because of the limited surgical field observed in these cases. The crescent clinical application of this method is also observed in small animal surgery ${ }^{1-5}$.

The stabilization of mandibular defects with miniplates has also been performed in humans and animals for mandibular reconstruction with bone grafts or synthetic composite bone substitutes ${ }^{4,6-9}$.

The objective of this study was to evaluate the use of maxillofacial miniplate 1.5 in the repair of segmental mandibular defects filled with autogenous bone in cats. We hypothesized that these miniaturized implants could offer enough stability to provide incorporation of the cortico-cancellous autograft.

\section{Methods}

This study was approved by the Ethics Committee for Animal Research of UNESP, Araçatuba-SP, Brazil.

\section{Animals and experimental design}

Twelve healthy young adult (aging between 12 and 18 months) mixed breed cats (weighing $2.9 \quad 0.2 \mathrm{~kg}$ ) were utilized. Six spayed females and 6 neutered males were used and evenly distributed between 2 groups. A segmental defect of $4 \mathrm{~mm}$ was created at random in either the right or the left hemimandible and filled with autogenous iliac crest bone graft. The operated hemimandible was fixed with a $1.5 \mathrm{~mm}$ titanium miniplate. In group $1(\mathrm{n}=6,2.8 \pm 0.2 \mathrm{~kg})$, the defect was performed in the body of the mandible, behind the $1^{\text {st }}$ molar. In group $2(n=6,3.0 \pm 0.2 \mathrm{~kg})$, the defect was performed between the $4^{\text {nd }}$ premolar and $1^{\text {st }}$ molar, with extraction of the $1^{\text {st }}$ molar. The cats were euthanized at 20 weeks postoperative.

\section{Surgical procedure}

Food was withheld for 12 hours prior to anesthesia. The cats were premedicated with atropine $(0.05 \mathrm{mg} / \mathrm{kg} \mathrm{SC})$, xylazine $(2 \mathrm{mg} / \mathrm{kg} \mathrm{SC})$ and ketamine $(15 \mathrm{mg} / \mathrm{kg} \mathrm{SC})$. Thiopental $(5 \mathrm{mg} / \mathrm{kg}$ IV) was administered to allow endotracheal intubation. Inhalation anesthesia was maintained with halothane and oxygen. Fentanyl $(0.0125 \mathrm{mg} / \mathrm{kg} \mathrm{IM})$ was administered after anesthesia induction. Lactated Ringer's solution (10ml/kg IV) was administered throughout anesthesia. Ketoprofen $(2 \mathrm{mg} / \mathrm{kg} \mathrm{SC})$ was administered preoperatively and for 3 days postoperatively. Enrofloxacin $(5 \mathrm{mg} / \mathrm{kg} \mathrm{SC})$ was administered preoperatively and for 5 days postoperatively. Each cat received $1 / 4$ pill of spiramycin $(187.500$ UI) in association with metronidazole $(32.25 \mathrm{mg})$ every 24 hours, 3 days preoperatively and for 7 days postoperatively.

Cats were positioned in lateral recumbency and the iliac crest region was clipped, prepared, and draped under sterile technique. Using a $\mathrm{n}^{\circ} 10$ Bard-Parker blade, a $4 \mathrm{~cm}$ incision was made over the iliac crest. The subcutaneous tissue, gluteal fat and thoracolumbar fascia were incised to expose the crest and the wing of the ilium. A block of cortico-cancellous graft was harvested from the iliac wing with an osteotome and mallet and stored in saline at room temperature. Subcutaneous layer was closed with 3-0 polyglicolic acid. Skin closure was with 4-0 nylon.

Thereafter the cats were positioned in dorsal recumbency. Local anesthesia of the inferior alveolar nerve was done with mepivacain $(7 \mathrm{mg} / \mathrm{kg})$ and epinephrine. The ventral cranial and cervical regions were clipped, prepared, and draped under sterile technique. A ventral surgical approach to the mandible was performed. The hemimandible was transected transversely. Initially a gap was performed in the cortical bone of the lingual and buccal surfaces and the ventral border with a burr on a lowspeed hand-piece under watering. Another gap was done distally at a distance of $4 \mathrm{~mm}$. Next, the two osteotomies were completed with an osteotome and mallet. In group 1 , the defect was performed 
in the body of the mandible, behind the $1^{\text {st }}$ molar. In group 2, the defect was performed between the $4^{\text {nd }}$ premolar and $1^{\text {st }}$ molar, with extraction of the $1^{\text {st }}$ molar. The gingival mucosa was sutured with 4-0 polyglactin 910. The hemimandible was fixed with a 6-hole titanium miniplate 1.5. The miniplate was applied with 4 bicortical screw placement on the ventrobuccal aspect of the hemimandible. The segmental defect was filled with autogenous iliac crest bone graft. Subcutaneous layer was closed with 4-0 polyglactin 910 . Skin closure was with 4-0 nylon. Skin sutures were removed after 7 days.

\section{Postoperative observations and radiographs}

Oral alimentation was reinitiated 24 hours after surgery with canned food. This soft food was offered during 6 weeks. After this period, the animals were feed with commercial dry feline diet. Cats were weighted again at the end of the study $(3.1 \pm 0.4 \mathrm{~kg})$.

Radiographs were performed one week after surgery and at the end of the study, i.e., after 20 weeks postoperative. The oblique lateral and ventrodorsal views of the mandible were taken. Intraoral radiographs were also performed.

\section{Macroscopic analysis, histolopathology and histometry}

Cats were euthanized at 20 weeks postoperative by intravenous thiopental overdosage. The operated and unoperated hemimandibles of each cat obtained at necropsy were fixed in $10 \%$ formaldehyde solution. Then, each of these hemimandibles was divided longitudinally into two segments. The superior half was demineralised in an aqueous solution of 5.66 formalin $10 \%$ to 1 of nitric acid $(\mathrm{v} / \mathrm{v})$. The demineralised specimens were dehydrated in ethanol, clarified in xylol and embedded in paraffin. Thin sections were made and stained with hematoxilin-eosin for microscopic evaluation. The inferior half was processed undecalcified. The undecalcified specimens were dehydrated in ethanol, clarified in xylol and embedded in glycol methacrylate. The sections were stained with Masson-Goldner for microscopic evaluation.

For the histometric analysis, the images of sections were acquired using a digital camera (Olympus DP71) coupled to a microscope (Olympus BX61). The percentage of newly formed bone in rostral and caudal mandible/graft interfaces was measured using the Image Pro Plus 6.1 software (Figures 1 and 2). The percentage of bone tissue of unoperated hemimandibles were also measured.

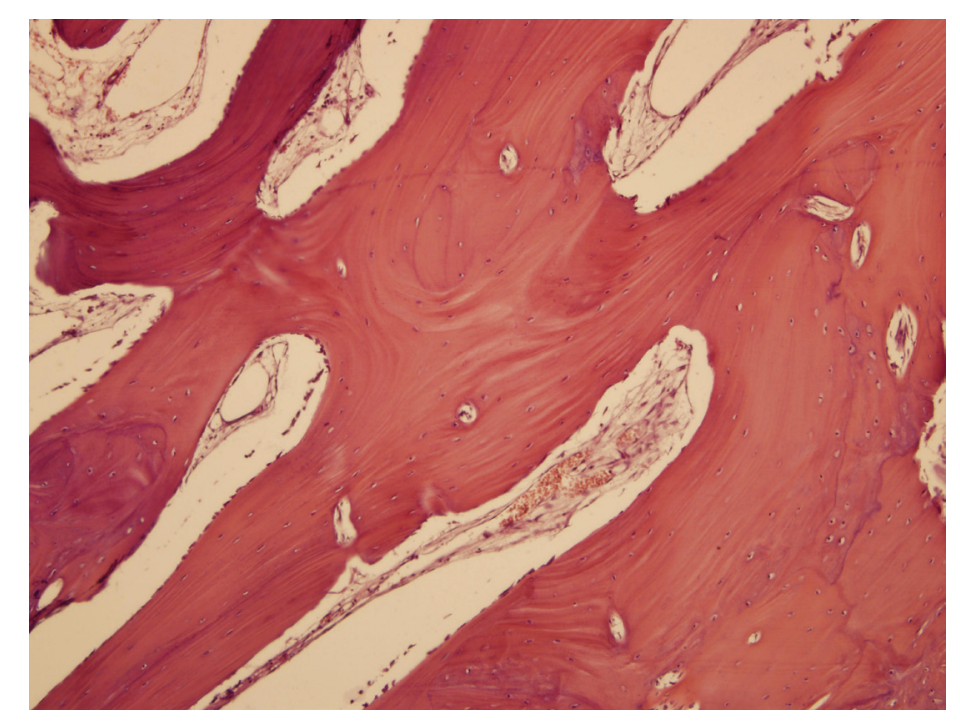

FIGURE 1 - Histologic section of the operated hemimandible of cat 23 of group 2 shows the mandible/graft interface at 20 weeks postoperative bridged by woven bone. Demineralised bone specimen. (HE -100X).

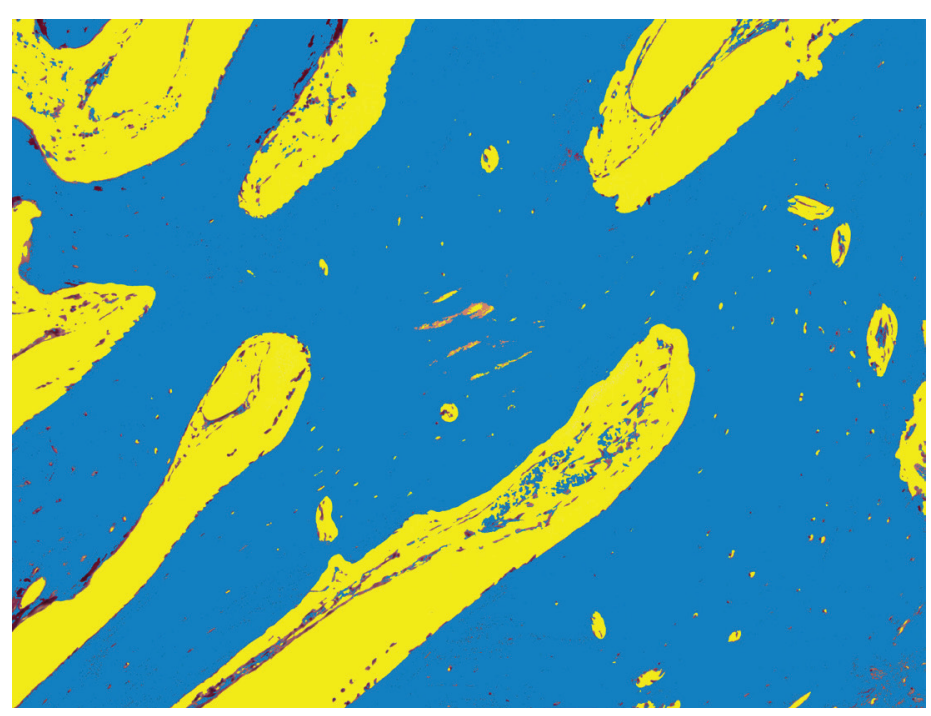

FIGURE 2 - The same histologic section prepared for histometry. The bone tissue was marked in blue and the soft tissue in yellow. Then the percentage of bone tissue was measured using the Image Pro Plus 6.1 software.

\section{Statistical analysis}

Non-parametric tests were utilized for the data analysis, taking into consideration the nature of the variables. MannWhitney's test was used to compare histometric data between the two groups. Significance was set at $\mathrm{p}<0.05$. 


\section{Results}

There were no clinical complications and the operated hemimandibles healed uneventfully and with appropriate occlusion. During the experimental period the cats showed normal activity and mastication and maintained their initial weight or even gained weight.

Postoperative radiography (intraoral, oblique lateral and ventrodorsal views) was useful in evaluating mandibular alignment and bone healing. Good reduction was obtained and maintained throughout the observation period of 20 weeks and no implant failure occurred. Incorporation of the graft was suggested by the radiographs taken 20 weeks after surgery (Figures 3 to 8 ).

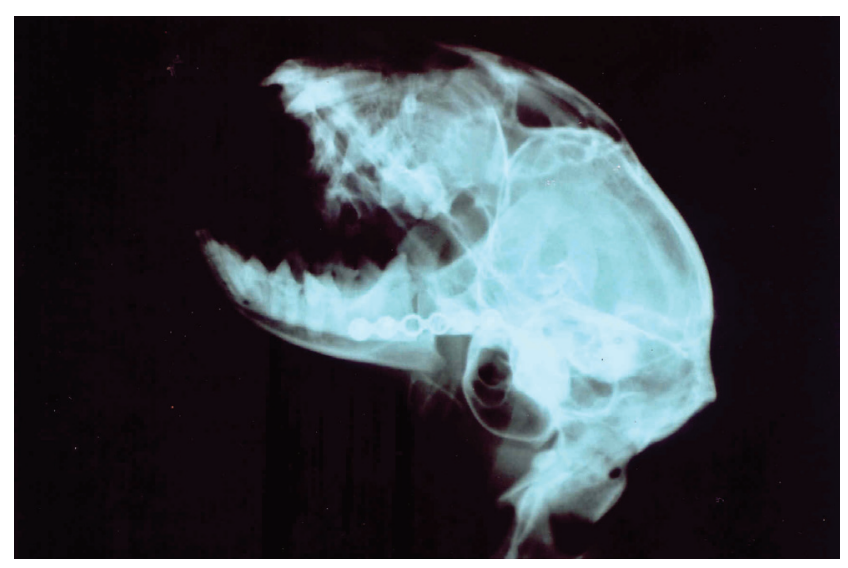

FIGURE 3 - Radiograph in oblique lateral projection taken 1 week after surgery shows the segmental defect filled with autogoneous bone graft. Cat 5 of Group 1.

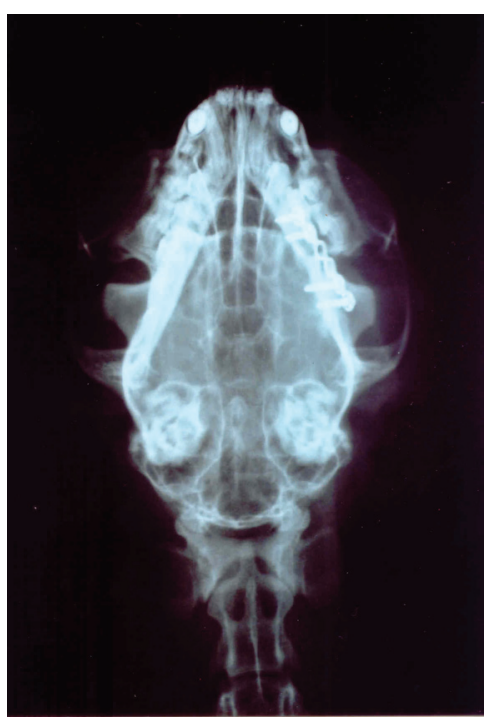

FIGURE 4 - Radiograph in ventrodorsal projection taken 1 week after surgery shows the segmental defect filled with autogenous bone graft. Cat 20 of Group 2.

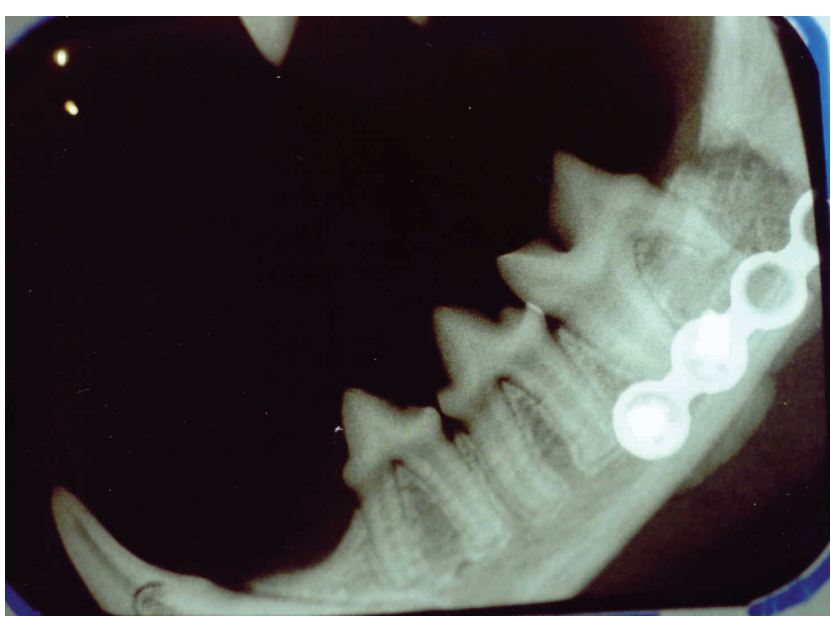

FIGURE 5 - Intraoral radiograph taken 1 week after surgery shows the segmental defect filled with autogenous bone graft. Cat 14 of Group 1.

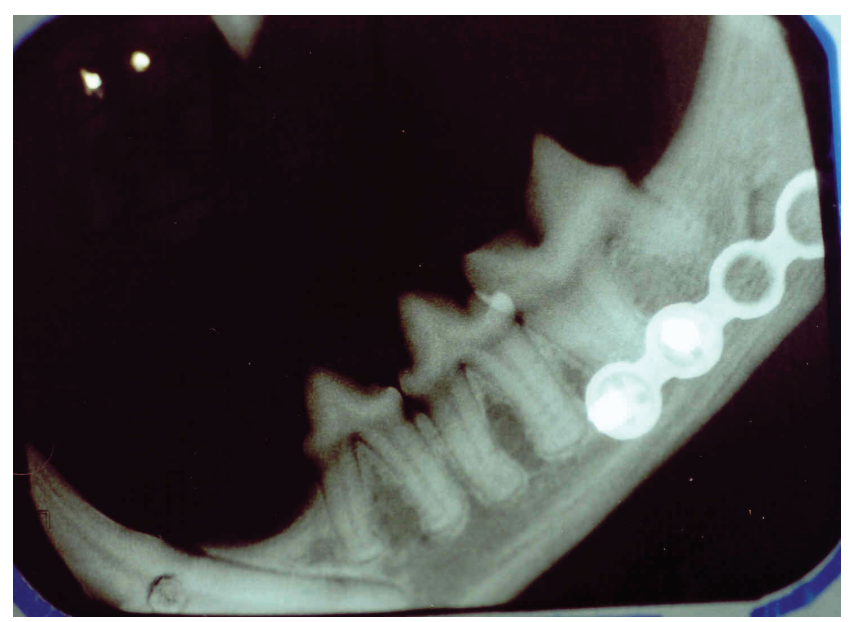

FIGURE 6 - Intraoral radiograph taken 20 weeks after surgery shows incorporation of the graft into the segmental defect. Cat 14 of Group 1.

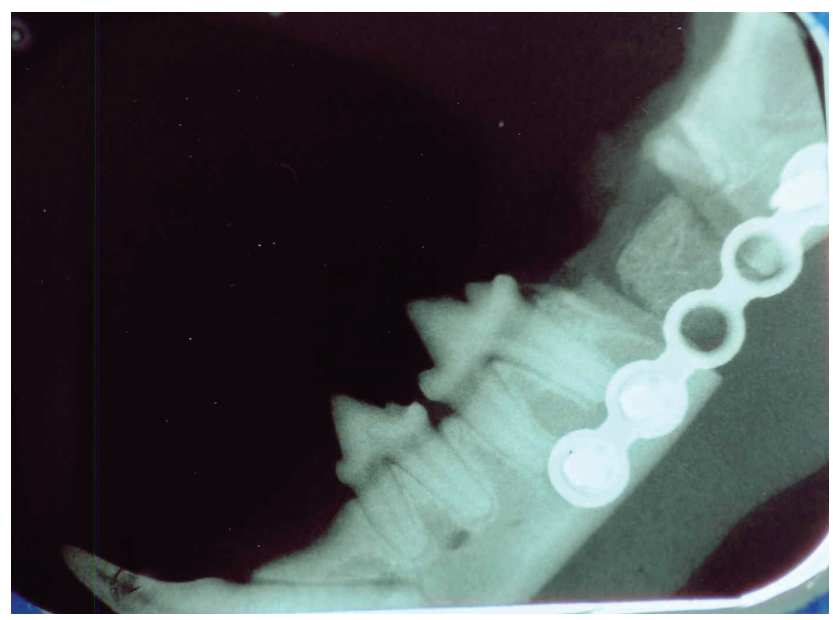

FIGURE 7 - Intraoral radiograph taken 1 week after surgery shows the segmental defect filled with autogenous bone graft. Cat 20 of Group 2. 


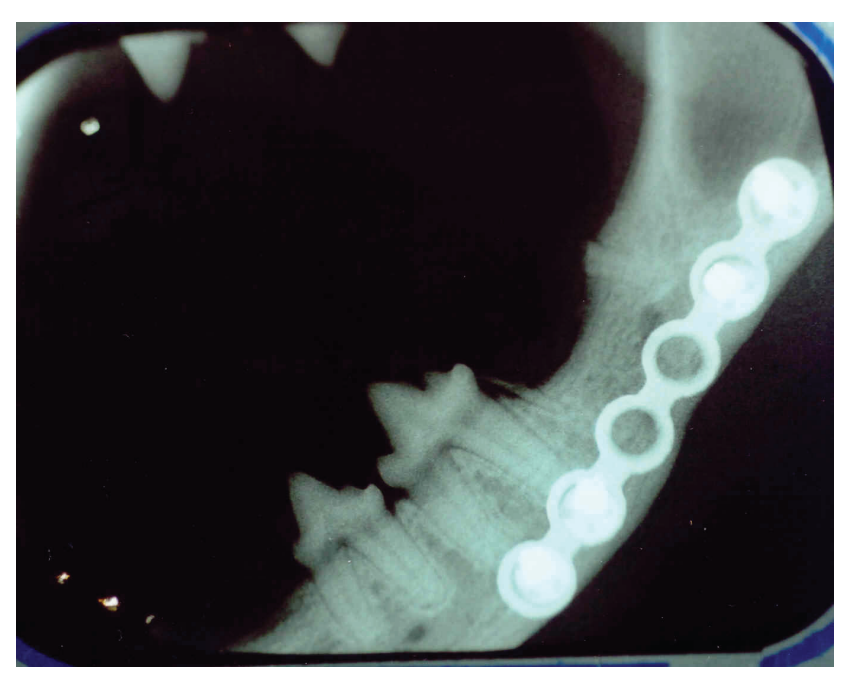

FIGURE 8 - Intraoral radiograph taken 20 weeks after surgery shows incorporation of the graft into the segmental defect. Cat 10 of Group 2.

Macroscopic examination confirmed the alignment and bone union of the operated hemimandibles. Normal dental occlusion was also observed. Histological examination showed formation of woven bone in rostral and caudal mandible/graft interfaces (Figures 9 and 10).

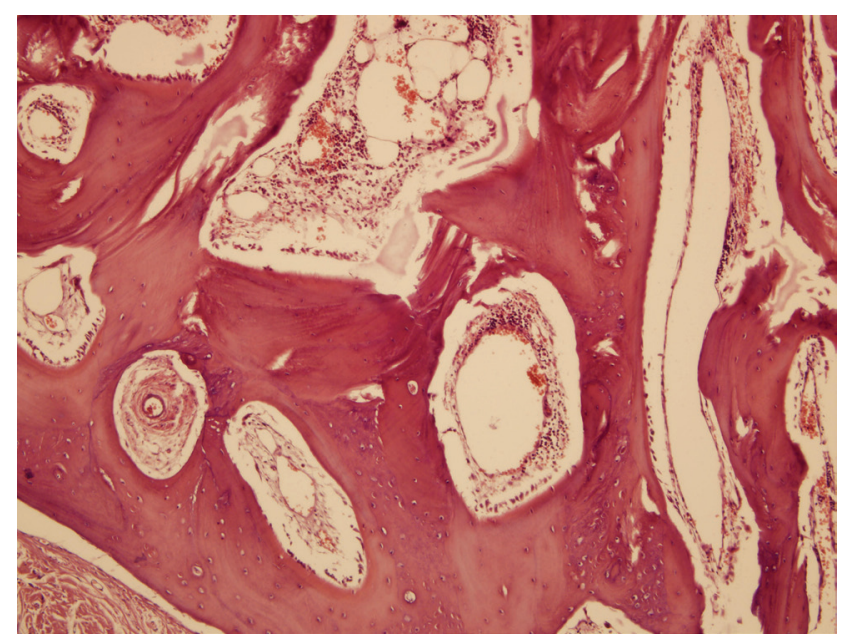

FIGURE 9 - Histologic section of the operated hemimandible shows that the mandible/graft interface was bridged by woven bone. Cat 22 of Group 2 specimen. (HE - 100X).

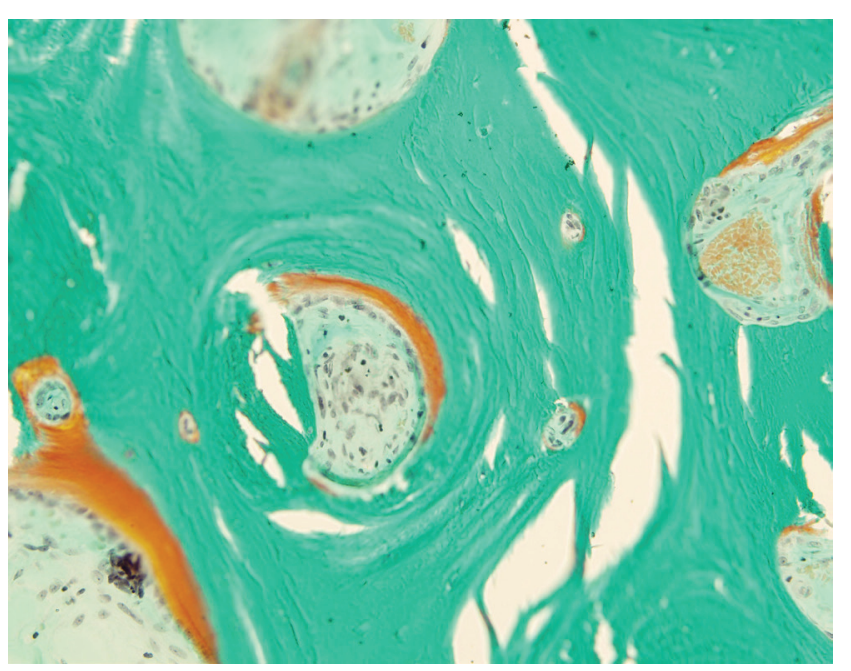

FIGURE 10 - Histologic section of the operated hemimandible shows that the mandible/graft interface was bridged by woven bone. Mineralised bone: green. Osteoid: orange. Cat 21 of Group 2 specimen. (MassonGoldner - 200X).

The percentage of bone tissue in the areas of graft incorporation was measured by the histo metry. There was no statistically significant difference between the values of group 1 (64.48 \pm 4.51$)$ and group 2 (71.69 \pm 14.47) (Mann-Whitney's test $p=0.294$ ) (Table 1$)$. These values were smaller from those observed in unoperated hemimandibles (Group 1: $90.08 \pm 5.18$; Group 2: $90.32 \pm 4.40$ ).

TABLE 1 - Bone fill percentage in rostral and caudal mandible/graft interfaces of operated hemimandibles of group 1 and group 2 .

\begin{tabular}{lcc}
\hline Statistic & Group 1 & Group 2 \\
\hline & 60.00 & 54.79 \\
& 60.18 & 58.58 \\
& 62.25 & 66.50 \\
& 66.28 & 77.50 \\
& 68.92 & 79.43 \\
& 70.45 & 93.35 \\
\hline Mean & 64.48 & 71.69 \\
Standard deviation & 4.51 & 14.47 \\
Median & 64.27 & 72.00 \\
\hline Mann-Whitney's test & $\mathrm{P}=0.294$ & \\
\hline
\end{tabular}




\section{Discussion}

In the present study we used the same technique described by Boudrieau and Kudisch ${ }^{4}$. The miniplate was applied on the ventrobuccal aspect of the mandible in order to avoid damage to the teeth roots.

The use of a single miniplate provided enough stability to provide incorporation of the graft. In the present study a block of cortico-cancellous autograft was inserted in the segmental defect. The same procedure was adopted by Sverzut et al. ${ }^{10}$, that used a iliac bone graft to fill a $10 \mathrm{~mm}$ long segmental defect in the mandibles of dogs and by Schliephake et al. ${ }^{11}$ that used a calcium phosphate cylinder to fill a segmental defect of $35 \mathrm{~mm}$ long in the mandibles of sheep.

Special feed management and body weight monitoring must be considered in animals submitted to maxillofacial surgeries ${ }^{4-6,12,13}$. Our results showed that the use of a single miniplate provided a fixation stable enough to allow immediate oral alimentation. Besides that, the cats maintained their initial weight or even gained weight at the end of the present study.

Postoperative radiography demonstrated a good reduction throughout the observation period. Incorporation of the graft was suggested by the radiographs taken 20 weeks after surgery.

Bone healing, as manifested by radiopacity at the original osteotomy sites was indicated in the radiographs taken at 6 and 12 week postoperatively in an experimental study with goats which evaluated a segmental defect filled with an autogenous bone graft from the iliac crest mixed with platelet-rich plasma ${ }^{13}$. Similar results were obtained by Huh et al. ${ }^{8}$, as the radiographs taken at 6 week postoperatively showed incorporation of the original particulate bone mixed with platelet-enriched fibrin glue used to reconstruct a segmental defect of $15 \mathrm{~mm}$ length in the dog mandible.

In the experiment conducted by Yuan et al. ${ }^{9}$, a $30 \mathrm{~mm}$ long mandibular segmental defect was repaired either with an autologous mandibular segment or with a beta-tricalcium phosphate cylinder seeded with bone marrow stromal cells. In this study with dogs, bone union was achieved after 32 weeks, as detected by radiographic and histological examinations.

Alignment and bone union of the operated hemimandibles was confirmed at macroscopic examinations. Incorporation of the graft was confirmed by histological examinations that showed formation of woven bone in rostral and caudal mandible/graft interfaces 20 weeks after surgery.

The histometric examination showed no statistically significant difference between the values of group $1(64.48 \pm 4.51)$ and group $2(71.69 \pm 14.47)$. These values were smaller from those observed in unoperated hemimandibles (Group 1: $90.08 \pm 5.18$; Group 2: $90.32 \pm 4.40$ ).

In the experimental study of Choi et al. ${ }^{7}$, a $15 \mathrm{~mm}$ long segmental defect in the dog mandible was filled with the original particulate bone. Histometric examination showed that the percentage of neoformed bone tissue after 6 weeks postoperatively was $56.7 \%$ in the control group and $36.8 \%$ in the group treated with platelet-rich plasma. In another study, using the same experimental model, the highest percentage of neoformed bone tissue $(41.7 \%)$ was observed in the group in which particulate bone was mixed with platelet-enriched fibrin glue ${ }^{11}$.

In the experiment of Sverzut et al. ${ }^{10}$, the histometric examinations performed after an observation period of 6 months showed higher percentage of bone tissue in the group in which the $10 \mathrm{~mm}$ long semental defect of the mandible of dogs was filled with autologous bone graft $(60.98 \%)$ and in the group in which the graft was surrounded by a perforated polylactide membrane (77.99\%). Schliephake et al. ${ }^{11}$ evaluated the use of a calcium phosphate cylinder to fill a $35 \mathrm{~mm}$ long segmental mandibular defect in sheep. The histometric examinations performed 5 months after surgery showed higher percentage of bone tissue $(34.4 \%)$ in the group with cylinders seeded with osteoprogenitor cells.

The areas of graft incorporation were clearly located in histological sections of demineralised bone embedded in paraffin because this technique allowed preparation of $2 \mathrm{~cm}$ length samples. For this reason, these sections were chosen for the histometric examinations. These sections showed no significant disruption of the trabecular structure as bone trabeculae were thicker after an observation period of 20 weeks.

In contrast, histological sections of undecalcified bone embedded in glycolmethacrylate could be obtained only from small samples ( $5 \mathrm{~mm}$ diameter), as reported by several authors ${ }^{14-17}$. There was some difficulty in seccioning and most histological sections showed disruption of bone trabeculae. Nevertheless, sections of undecalcified bone can be stained with specific histological methods to differentiate mineralised from unmineralised matrix. In the present study, the Masson-Goldner stain provided clear differentiation between mineralised bone (green) and osteoid (orange), as described by Yang et al. ${ }^{17}$ As the operated hemimandibles showed an advanced stage of bone union, the presence of osteoid in histological sections was discrete. 


\section{Conclusion}

The use of miniplate 1.5 for the fixation of mandibular defects filled with autogenous bone in cats provided the main goals in the treatment of mandibular fractures: bone union, normal dental occlusion and immediate return to oral alimentation.

\section{References}

1. Champy M, Loddé JP, Schmitt R. Mandibular osteosynthesis by miniature screwed plates via a buccal approach. J Maxillofac Surg. 1978;6:14-21.

2. Ellis III E, Walker L. Treatment of mandibular angle fractures using one noncompression miniplate. J Oral Maxillofac Surg. 1996;54:864-71.

3. Freitag V, Landau H. Healing of dentate or edentulous mandibular fractures treated with rigid or semirigid plate fixation - an experimental study in dogs. J Craniomaxillofac Surg. 1996;24:83-7.

4. Boudrieau RJ, Tidwell AS, Ullman SL, Gores BR. Correction of mandibular nonunion and malocclusion by plate fixation and autogenous cortical bone grafts in two dogs. J Am Vet Med Assoc. 1994;204: 744-50.

5. Boudrieau RJ, Kudisch M. Miniplate fixation for repair of mandibular and maxillary fractures in 15 dogs and 3 cats. Vet Surg. 1996;25:277-91.

6. Schmelzeisen R, Rahn BA, Brenwald J. Fixation of vascularized bone grafts. J Craniomaxillofac Surg. 1993;21:113-9.

7. Choi BH, Im CJ, Huh JY, Suh JJ, Lee SH. Effect of platelet-rich plasma on bone regeneration in autogenous bone graft. Int J Oral Maxillofac Surg. 2004;33:56-9.

8. Huh JY, Choi BH, Zhu SJ, Jung JH, Kim BY, Lee SH. The effect of platelet-enriched fibrin glue on bone regeneration in autogenous bone grafts. Oral Surg Oral Med Oral Pathol Oral Radiol Endod. 2006;101:426-31.
9. Yuan J, Cui L, Zhang WJ, Liu W, Cao Y. Repair of canine mandibular bone defects with bone marrow stromal cells and porous betatricalcium phosphate. Biomaterials. 2007;28:1005-13.

10. Sverzut CE, Faria PE, Magdalena CM, Trivellato AE, Mello-Filho FV, Paccola CA, Gogolewski S, Salata LA. Reconstruction of mandibular segmental defects using the guided-bone regeneration technique with polyglactide membranes and/or autogenous bone graft: a preliminary study on the influence of membrane permeability. J Oral Maxillofac Surg. 2008;66:647-56.

11. Schliephake H, Knebel JW, Aufderheide M, Tauscher M. Use of cultivated osteoprogenitor cells to increase bone formation in segmental mandibular defects: an experimental pilot study in sheep. Int J Oral Maxillofac Surg. 2001;30:531-7.

12. Kern DA, Smith MM, Stevenson S, Moon M, Saunders GK, Irby MH, Dyer KR. Evaluation of three fixation techniques for repair of mandibular fractures in dogs. J Am Vet Med Assoc. 1995;12:188390.

13. Fennis, JPM, Stoelinga PJW, Jansen JA. Mandibular reconstruction: a clinical and radiographic animal study on the use of autogenous scaffolds and platelet rich plasma. Int J Oral Maxillofac Surg. 2002;31:281-6.

14. Islam A, Frisch B. Plastic embedding in routine histology I: preparation of semi-thin sections of undecalcified marrow cores. Histopathology. 1995;9:1263-74.

15. Islam A, Henderson S. Glycol methacrylate embedding for light microscopy I enzyme histochemistry on semithin sections of undecalcified marrow cores. J Clin Pathol. 1987;40:1194-200.

16. Wolf E, Röser K, Hahn M, Welkerling H, Delling G. Enzyme and immunohistochemistry on undecalcified bone and bone marrow biopsies after embedding in plastic: a new embedding method for routine application. Virchows Archiv A Pathol Anat Histopathol. 1992;420:17-24.

17. YangR,Davies CM,ArcherCW,RichardsRG.Immunohistochemistry of matrix markers in technovit 9100 new $^{\mathrm{r}}$ embedded undecalcified bone sections. Eur Cell Mater. 2003;6:57-71.

\section{Correspondence:}

Adelina Maria da Silva

Univ. Estadual Paulista-UNESP

Depto. Clínica Cirúrgica e Reprodução Animal

Rua Clóvis Pestana, 793

16050-680 Araçatuba - SP Brasil

Phone: (55 18)3636-1404

adelinasilva@fmva.com.br
Conflict of interest: none Financial source: FAPESP and FUNDUNESP

Received: November 10, 2010

Review: January 11, 2011

Accepted: February 14, 2011 